\title{
A non-fundamentalist return to origin: The new Islamic reformers' methodology of (re)interpretation
}

2020, Vol. 8(I) 25-38

(C) The Author(s) 2020

Article reuse guidelines: sagepub.com/journals-permissions DOI: 10.1 I 177/20503032I9900247 journals.sagepub.com/home/crr

(SAGE

\section{Mohammad Rezaei (D)}

Goethe University Frankfurt, Germany

\begin{abstract}
Focusing on some contemporary Islamic reformers' solutions, in particular, Abolkarim Soroush, Mohsen Kadivar, and Fazlur Rahman, to concrete issues in Muslim societies, this article examines two different methodological strategies of alternative readings of the Sunna: an archeological one and a genealogical one. In the archeological perspective, the holy text has been considered as a repository of answers to all sorts of questions. Through a pathological analysis, this view suggests solutions to correct distortions and looks for new windows seeking an original interpretation of the Qur'an. The genealogical view, on the other hand, puts aside this pathology and instead insists on the idea of the contingency of any interpretation. Regardless of accuracy and validity, according to the genealogical view, all interpretations have addressed temporal and contextual questions. What is important in this perspective is not returning to an original source for finding the exact message of Allah, or correcting previous interpretations, but recurrently referring to an open-ended text in order to explore the futures of the Qur'an.
\end{abstract}

\section{Keywords}

Functional approach to interpretations, Iran, method of historical hermeneutic, religious intellectualism, the evolution of religious knowledge, women problem

\section{Introduction}

The new Islamic intellectuals are a group of thinkers seeking a way to reconcile Islamic beliefs on one hand with modern ideas and practices on the other. Muslims in Pakistan,

\section{Corresponding author:}

Mohammad Rezaei, Frankfurt Research Center for Global Islam (FFGI), Goethe University Frankfurt, Frankfurt, Germany. Email: rezaei@em.uni-frankfurt.de 
Egypt, Iran, Saudi Arabia, and other Islamic countries face some problems that create a need for the ideas of these intellectuals, particularly for those who are concerned about maintaining religious beliefs in the modern world. In fact, this concern dates back from the first confrontations with Western thought. Since then three kinds of reactions in Muslim society, to use Arkoun's phrase ([1378] 2000), have emerged: traditional, ideological, and liberal. While the first demonstrates a kind of negligence and depreciation, the other two portray fundamentalist and secular approaches to current issues, respectively. All these responses were doomed to failure right from the start. None of these reactions provide Islamic societies with an effective balance between "the constant and the variable," in Abdolkarim Soroush's ${ }^{1}$ ([1370] 1992, 6) sense. Traditional and ideological interpretations ignore internal dynamics of Islamic societies, whereas secular responses underestimate the effective presence of tradition and religion in Muslim's lives.

How are balanced interpretations of the constants and the variables methodologically possible? Two main problems can be mentioned here. First, finding a plausible standard and agreed-upon criteria for discerning the constant from the variable is difficult. Second, a broad array of religious injunctions, such as Islamic veiling, turned sacrosanct over the centuries. Thus, a primary mission for intellectuals has been the de-sacralization of what was once indeed profane (see Arkoun [1374] 1996). Now the key point is how intellectuals approach the issues and what kind of solutions they propose.

The new religious intellectuals are concerned with linking religion to modern thought. Accordingly, their approaches differ from those of secular intellectuals and religious fundamentalists. As far as Iranian religious intellectuals are concerned, some of them are reformist clerics while others are educated in Western universities. They not only came to criticize religious dispositif in Foucault's well-known sense (1977), but they paved the ground for new interpretations of Islam in general and Shi ism in particular. In fact, through their so-called heresies, ${ }^{2}$ they have reformulated some current issues, including women problem and human rights. As we know, particularly in Iran, their voices provided ordinary people with new subjectivities, in contrast to state-led cultural engineering (Golkar 2012; Tajmazinani 2017). Precisely speaking, in comparison to the traditional Shi i fiq, which showed an inability to take a proper position vis-à-vis emergent issues such as the problems facing women, the alternative narratives have the potential to open new rooms for being Muslim. In sum, these new approaches mainly concern themselves with the ontology, epistemology, and history of Islam in general and Shi ism in particular, focusing on Islamic sources of knowledge.

In what follows, by drawing upon contemporary Iranian religious intellectuals such as Abdolkarim Soroush (1945-), Mohsen Kadivar (1959-), Ahmad Ghabel (1954-2012), and Fazlur Rahman Malik (1919-1988) instead of seeking clear reinterpretations, I argue how alternative religious readings can be methodologically possible. In other words, I demonstrate that their legacies make some functional clues available, clues with which one can deal with concrete issues in the Islamic world. As far as Iranian intellectuals are concerned, their works have been studied by some scholars (Boroujerdi 1996; Mirsepassi 2000, [1380] 2001, [1381] 2002; Jahanbakhsh 2003, 2004; Khavar 2004; Ghobadzadeh and Rahim 2012; Adib-Moghaddam 2015; Safari 2015), but their methodological contributions remained unnoticed. Most of these critical studies are concerned with the relationship between Islam and secular democracy. In this article, I contend that the new religious intellectuals, through their non-fundamental appeal to the foundations of Islam that are the Qur'an and Hadith, attempt to present new solutions to the problem of being Muslim in the contemporary world. 


\section{Return to the Qur'an itself and re-establishment of Shari 'a}

In a world that is based on incessant changes, even to foundations, religious intellectualism seeks a kind of non-fundamental Islamic modernity - despite its adherence to the original text, the Qur'an. One may connect these various endeavors with the idea of returning to the unfinished future(s) of the Qur'an. Religious intellectuals believe that the Qur'an is an open-ended text with unlimited possibilities. This idea indeed stems from their faith in the Qur'an as a miracle, which makes it an ever-present agenda for living. Thus, the idea of nonfundamentalist interpretations of the fundamental text is justified. Considering the significance of the idea, the methodology of returning to the Qur'an should be subjected to close scrutiny. In their journey to the origins, new reformists examine various routes, including the differentiation of religion from religious knowledge, casting light on lexical arguments such as Ghabel's ([1392] 2014) work on the term qawām in the popular sura an-Nisā, verse 34, or fundamental criticism of Sunna in Rahman's (1984) work, and so on. What is common to all of these efforts is the search for a new reformist and temporal understanding of the Qur'an. To my knowledge, except in cases of extremist and radical readings that are aimed at discovering patterns pre-existing the Prophet's time, the idea of a return is, for religious intellectuals, a kind of methodic journey where finding a temporal, rational, and critical way of re-interpreting is at stake.

Method of historical hermeneutic. Through illustrating concepts such as Sunna, ijma', and ijtīhād in Islamic Methodology in History (1965), modern Pakistani scholar Fazlur Rahman Malik put forward some methodological clues that, in his later book Islam and Modernity (1984), reached maturation. His claim is an invitation to "a historically systematic study" (146) of Islamic heritage through a wholesale and multi-faceted investigation engaging different disciplines, including fiq (Islamic law), hikmat (Islamic philosophy), history, and so on. His method was to examine the evolution of Islam in order to purify Islamic interpretive heritage that had been infected by or derived from "atomistic" (2) approaches. According to Rahman, shari a is full of interpretations, rules, and norms that came to the fore without reference to "the Qur'an as a unity," (4) to which, separate verses set the stage for the Qur'anic deductions and the foundation of the tradition. In some cases, philosophical and $S \bar{u} f \bar{\imath}$ approaches provided the context out of which holistic views came to exist, but they were influenced by external intellectual sources such as Greek and ancient Persian thought. Rahman instead emphasizes an internal holistic reading of the Qur'an and argues that all these unsuccessful readings are "piecemeal, ad hoc, and often quite extrinsic treatment of the Qur'an" (1984, 4). Accordingly, he introduces "the method of Qur'anic hermeneutic," (4) which requires "double movement" (6) between two different times: a two-way journey between the time of the revelation and the present. Perhaps more precisely, an understanding of the historical time of the Qur'an requires scholars to analyze more closely the historical background, the totality of the text, and Allah's responses to the concrete issues of a newly established Muslim society.

Rahman's approach has its benefits: first, a holistic method not only makes an understanding of Allah's messages in their historical ground possible, but it also connects piecemeal responses to concrete problems through the universal messages of the Qur'an. Furthermore, a sensitivity to the particulars and the universals of the holy text allows Rahman to separate his method from reactionary and fundamentalist interpretations and return to origins dating back to various movements, including neo-revivalism or 
neo-fundamentalism. As Rahman illustrates, all these approaches stem from the eighteenth century Wahhabi movement and some neo-fundamentalists groups such as Ikhwan. The reconstruction of Islam through a return to "the pristine purity of Islam" (136) has been the main plea of these movements. Rahman, in turn, suggests that returning to the Qur'an does not equal returning to the holy past but is instead a resort to the original text, or, as I established earlier, a return to the potential futures of the Qur'an. Second, Rahman differentiates his perspective from modernist approaches to Sunna, which are premised on at least two inefficient agendas: the modernizing of the old and the Islamization of modern secular institutions. All of these programs culminated in a "mechanical juxtaposition" (141) of the past with the present. One could argue that Rahman's endeavor, particularly in Islam and Modernity, foregrounds an Islamic modernity that defines itself as a normative Islam instead of an historical one. Although it is hard to find a plausible illustration characterizing normative Islam, it can be considered as the potential outcome of his method of reinterpretation.

The silent shari ' $a$ and the evolution of religious knowledge. Returning to the origin in search of a new agenda for a religious life can be approached in two ways. First, one may argue that most narratives and interpretations since the revelation "the historical Islam" in Rahman's $(1984,141)$ sense, are distorted. The point is, nobody can present clear-cut evidence that all historical narratives or forms of Islam after the revelation have misconstrued the origin. It seems that all of these versions of Islam, instead, can be considered to be various responses to historical concrete issues. Moreover, a return to the origin by way of Rahman's suggestions may be in danger of fundamentalist encounters with the past (the time of the revelation and the Prophet's society) since his historical hermeneutic method not only resorts to the origin, but also seeks an original interpretation. In contrast, scholars such as Soroush distinguish between religion (including the Qur'an and the Sunna of the Prophet) on one hand and interpretations, or religious knowledge, on the other. This methodic agenda is concerned with a systematic and plausible balance between change and stability, which has little to do with righting historical Islamic fallacies. Quite the contrary, all forms of religious knowledge are envisioned as temporal and directed to concrete historical problems. Simply put, the idea of a return to the origin is a perennial constituent and a prerequisite of religious life.

Soroush (1996) describes the Qur'an as a silent text that is always open to numerous possible readings. Similar to a learned man, various answers can be expected depending on the depth and the types of questions. Nevertheless, questions are historical in the sense that they are situated within the framework and the epistemological horizon of their own time. Hence, Soroush contends that interpretations (or Qur'anic answers) function as historical impositions. The silent text, like a mirror, reflects socio-culturally situated expectations and fulfills the historical needs of the day. Unlike Rahman's theory, which considers the simple historical background of the revelation, history plays more extensive roles in Soroush's theory, since he replaces the historical background of verses at the time of revelation with the historicity of interpretation. In other words, he tries to illustrate that the interpreters' different points determine their various points of view. In the shadow of the idea of silent shari 'a, Soroush (1996) introduces the idea of "the pluralism of interpretations," by which he casts doubt on the politico-ideological and dominant religious interpretations in Iran in favor of a religious democratic society.

Notwithstanding his defense of pluralism, Soroush is conscious about the methodological rigor of interpretation. But who has the right to perform interpretation? He argues 
everybody can have her own reading, but he differentiates scholarly narratives from ordinary understandings of religion and warns of unscholarly encounters with the Qur'an and Islamic history. As far as ordinary people are concerned, he refers to an unsophisticated religious experience that is usually common among all ordinary religious people (Souroush [1376] 1998a) ${ }^{3}$ and argues that interpretations cannot be performed arbitrarily. Conversely, the temporality of interpretations is the very characteristic of the methodology of (re)interpretation; thus he suggests that scholarly readings require technical and methodological seriousness. This can be found in his theory of the evolution of religious knowledge.

Appealing to several important axioms, Soroush lays the foundations of his theory. First, there is a mutual interplay between various sciences that makes a dialogue among them possible. ${ }^{4}$ Second, our worldview and how it changes both hinge upon our material and nonmaterial world. Third, the sacred (religion or the Qur'an and the prophet's Sunna) is eternal, but the human understanding of religion and divine scripture is subject to continual evolution. Furthermore, he insists on a fiqa pūy $\bar{a}$ (dynamic jurisprudence), which underlies temporal understandings of the Qur'an, and effective ijtīha d, or "ijtīhād in principles," which are prerequisites for Islamic dynamism ([1372] 1994). Soroush presents a worthwhile example ([1376] 1998b) to illustrate the idea in his discussion with Ayatollah Muntaziri about the rule of $\operatorname{taz}_{\bar{a}} \mathrm{hum}^{5}$ (contention or conflict) and the issue of retaliation (qis $\bar{a} s$ ). Soroush argues that instead of ad hoc and piecemeal amendment, Muslim scholars should look for changes in the foundations $(\bar{u} s \bar{u} l)$ and in their preconceptions about humanity and rationality. He suggests ([1376] 1998b) that in the modern world there is no room for petty reforms, only new fundamental ones. ${ }^{6}$ In addition to the possibility of and the need for great changes, Soroush accepts the idea of a "better understanding" (13) that foregrounds the evolutionary character of religious knowledge. He indicates that regardless of the intention of Allah, the meaning of Qur'anic words or the whole text changes over time. Simply put, following Soroush ([1370] 1992), our understanding not only changes with the passage of time, but a more comprehensive perception becomes potentially accessible.

What makes this idea important for my discussion here is its relevance to the methodology of reinterpretation. As it is clear, the epistemological and methodological conditions of a better and evolutionary understanding require Soroush to respond to some critical questions, including ones that seek to explain which criteria one must use to judge different understandings. The more he depicts the epistemology of reinterpretation, the less he pays attention to the method(s) of better understanding and the criteria of judgment. In turn, he simply asserts that interaction and dialogue between different knowledge types catalyze the conditions of better understanding. By saying this, Soroush obviously shows his debts to Rumi's story about the elephant in a dark room. In his sense, the only methodic condition underlying a more comprehensive knowledge, or multi-faceted perception, is to light the dark room. Accordingly, everyone can figure out how much her knowledge has been partial and incomplete. But who can light the room? And how can man reach the light(s)? It is hard to find due explanations for these questions in Soroush's theory of Constriction and Expansion of the Shari' ${ }^{7}{ }^{7}$

\section{Transition from historical Islam to spiritual Islam}

Seeking more appropriate methods of returning to the Qur'an and obtaining proper responses led Mohsen Kadivar ([1382] 2004) toward distinguishing between "tradition-blind intellectuals" and "present-blind traditionalists." In his distinction, one 
can figure out how to balance the past and the present - or the constant and the variable - in Islamic tradition. Kadivar presents two types of Islam: the historical, which echoes Fazlur Rahman's category of historical Islam, and the spiritual, which is associated with the substance of religion instead of its form. In both approaches, time stops moving, but in two different ways. The historical one seeks an authentic Islam through a return to the time of the revelation and the Prophet's behaviors. In this view, finding an archetype is at stake, which is where Salafism and radical Islam have their roots. In contrast, time has gone in a different but positive form in spiritual Islam in the sense that Islam-like any other religion - consists of form(s) and substance(s). Regardless of present conditions, traditionalists, based on instrumental rationality or religious expediency (Kadivar [1380] 2002), look for an already established form. Through spiritual Islam, religious intellectuals probe the history of Islam looking for the spirit or final end of religion, including piety and virtue. While historical Islam is ritualistic and aims to expand itself throughout the everyday lives of Muslims, moral Islam tends to expand ethics and contemplation among Muslims. In sum, through spiritual Islam, Kadivar illustrates how the potential capacities of Islam justify religious life in the modern age. Let us follow the controversy by considering the problems of justice and equity, human rights, and the problems facing Muslim women.

The problem of human rights and reform. The current Islamic legal system, according to Kadivar ([1396] 2018), relies on an essential inequality that is based on religious and natural differences. Hence, he concludes that historical Islam is characteristically incompatible with human rights. As far as shi a fiq is concerned, in Kadivar's sense, four unequal groups of people are distinguishable. The first are al-Muminūn, or Muslims belonging to the majority denomination who enjoy all religious rights. The second category is judicially second-ranked Muslims, who represent other Islamic denominations, such as Sunnis in a Shi'a society or vice versa. These people enjoy most religious rights. Believers of other legally accepted religions, such as Christians, Jews, Zoroastrians in Iran, and non-Muslim people from other countries that have signed a treaty with Islamic states, constitute the third group. These people can live in Iran but without the benefits of most religious laws. Finally, unbelievers, infidels ( $k \bar{a}$ firün), and all so-called aberrant Islamic denominations form the lowest rank of citizens in a Muslim society. As this classification suggests, people enjoy discriminatory rights based on their religious beliefs rather than basic human rights. Therefore, the Declaration of Human Rights, which is based on the dignity and rights of all human beings (article 1), negates any forms of discrimination and underscores basic freedoms (article 2), emphasizes the right to life, liberty and personal security (article 3), and insists on equality before the law (article 7), cannot be consistent with traditional and historical Islam (see also Soroush [1376] 1998a).

Gender is the second axis of discrimination in historical Islam. Although in many cases, such as commercial law, men and women are equal, they are unequal before civil and criminal law. In a few cases, women even enjoy more legal privileges, such as receiving alimony, exemption for taking part in war and jihād, and impunity for apostasy. In contrast, women are deprived of five important positions: Marja iyyat (being a source of religious imitation), judgment, guardianship (velāyat or political and religious leadership of a Muslim society), and imamat. ${ }^{8}$ In addition, women have unequal rights in cases such as testimony and diya (blood money). In both cases, women's diya in most Islamic societies, is half that of men. 
The theory of true human rights, as Kadivar argues, is where this notion of discrimination lies, on which Allah considered as the final source of true rights and incorporated these constant and divine laws into the holy text. But surprisingly, nobody, simply through means of human reason, can extrapolate the implied meaning, and thus making sense of the real rights remains enigmatic and unreachable. In the absence of potent human reason, the only way of knowing these rights is to superficially refer to the Qur'anic statements or to the traditions and the Prophet's behavior. Nevertheless, one should be careful about the exact position and value of reason, as one of the sources of knowledge in the Islamic intellectual tradition, along with other important tools, namely consensus ( $i j m \bar{a})$. Here, the role of reason is too limited to uncover pre-existing religious rules. Islamic reason thus has limited discovery power and cannot go further to reach reflection, or what is known as critical and autonomous reason in modern thought. Islamic reason is dependent on other sources of knowledge, including divine revelation and tradition. On this basis, Kadiver argues, the Islamic ulima approves that human reason's fundamental imperfection prevents it from uncovering true human rights. ${ }^{9}$

Kadivar opens the space for a potent form of religious reasoning that has fewer limitations in the face of established ahkāmi dīn̄ (religious rulings). In doing so, he mainly seeks a type of reflective reasoning that is not necessarily in conflict with the revelation, but is rather a source of fresh and fundamental interpretations. He replaces the aql-wahy (reasonrevelation) dichotomy with aql-naql (reason-tradition), supporting the fact that all religious intellectuals assume there to be no inconsistencies between reason and Allah's messages (the principle of muläzima aql va dìn). Kadivar contends, however, dealing with aql requires intellectuals to enter the territory of criticism - though it should not be a trenchant criticism of the Qur'an itself. Critical reasoning here tends to be applied differently but is still in line with scholarly judgment, investigation, and interpretation - far from accepting an imitative and faith-based appraisal of the Sunna. Altogether, imitative aql is merely able to perform discovery and judgement among proper and improper existing ahkāmi dīn $\bar{\imath}$. Judgment in this way is confined to the validity of the source of statements (or rules), namely the holy text and/or the great speakers (The Twelves in the Shi ${ }^{\prime} a$ denomination and the salaf [ancestors] ${ }^{10}$ among Sunnis). Therefore, wisdom has nothing to do with its contemplation and reflection; rather, by drawing on qiyās (reasoning and comparison by analogy), new rules can be discovered. Critical aql seeks to go beyond the analogy to find new possibilities for an autonomous criterion (see also Alavitabar [1380] 2002).

The modifications to the concept of reason by religious intellectuals are associated with other revised concepts, such as equality. Intellectuals distinguish between two different approaches to equality: proportional equality (musāvāti tanāsubì) and basic equality (musāvâti bunyādì). Each of these concepts leads to a different kind of justice in Muslim society, including entitled justice (idālati istihqāq $\vec{l}$ ) and equity-based justice (idālati $m u s \bar{a} v \bar{a} t \bar{t}$ ), respectively (Kadivar [1390] 2012). The first notion concerns itself with the physical and natural differences between men and women, such as the fertility of women, feminine subtlety and sentiments, the so-called lack of reason $(a q l)$ in women, and so on. A number of verses referenced by the ulima seem to be in accord with proportional equality, including the exaltation of men or more rights (The Qur'an 2: 228 and 4: 34), an unequal share of inheritance (The Qur'an 4: 32), and distinct desires and characteristics (The Qur'an 43: 18). The point is that all of these distinctions are deemed perennial by the traditional ulima $\bar{a}$, and none of them seem to be surmounted. Hence, the so-called physical and sentimental weaknesses of women make them dependent on a guardian and thus not competent 
enough for political, judicial, or religious leadership roles in a society. One can see here a clear distinction between general and personal virtues. It is believed that men and women are the same in the first category, such as faith and abstinence (taqwā), but are completely different based on the second measure. The personal virtue of a woman is her right to receive a dowry (mahr) and alimony, and men's private virtues are their competence to participate in jihād, judgment, leadership, and so on. Nevertheless, basic equality and equity-based justice have always been at the center of Islamic jurisprudence. A broad array of verses in the Qur'an corroborate the idea of basic equities, including similar creation (The Qur'an 49: 13, 4: 1), the same quality of salvation (The Qur'an 16: 97, 33: 35), the equal rights and obligations (The Qur'an 9: 71), equal rights to rewards and punishments (The Qur'an 48: 5-6, 57: 12-13, 5: 38, 24: 2-3), and equity in marriage (The Qur'an 2: 187, 30: 21).

Instead of a tough choice between these two aforementioned approaches, Kadivar (2018) believes that a stable balance between them is feasible. Despite the Qur'an's emphasis on al-qist (equity), for example, there is no clear definition of it in the Sunna. It is believed that Allah delegated defining the limits of the term to the Muslims. Moreover, justice and equality can be defined a priori without any reference to religion (Kadivar [1382] 2004). From my point of view, drawing on an extra-religion point of reference in the course of religious thinking is a radical and considerable achievement that allows religious intellectuals to expand their power of reasoning and open new rooms for critical insights. First, it provides space for additional sources for evaluation and judgment, which is not simply confined to internal religious perspectives. Second, through the complex interplay of different sources of knowledge, particularly the effective role of more overwhelming criteria, religious intellectuals can highlight the functional assessment of religious norms and values. Considering religion as an instrument in making people's lives more humane paves the way to go beyond essentialism, legalism, and formalism. Indeed, these qualities are the basic components that have caused Islam to be inconsistent with modern social conditions. The functional perspective, on the other hand, focuses on subjective interpretations and concrete rituals as temporal, historically-situated statements and behaviors that satisfied time-bonded needs.

How would a functional view be possible in religious debates? Kadivar ([1382] 2004) contends that it was a prevalent approach at the outset of Islam. Islamic rules, as he argues, primarily focused on the Arab's concrete needs and the lack of an adequate agenda for social welfare, and Islam in turn presented new and more functional moral laws for social living. In other words, unlike the old rituals, the new rituals were based on the judgment of common sense and were more rational and ethical than the prevailing norms in other societies, such as the Persian and Greek. Laws that are sensitive to women, for example, paint a more realistic picture of functional religion. Before the Islamic prophetic revelation, considerable gender inequalities were prevalent among the Arab clans. While women could not enjoy any real rights, in the Qur'an, it states that Allah suggested equal access to social and personal rights for Muslim women. The point that ulima and the Muslim thinkers need to take into account is the idea that the first agenda is not the final one. In fact, it was the product of a historical moment with particular needs that required relevant temporal answers. Moreover, if we imagine that the first Islamic rules were just one step in a long course of a gradual social equalization, it would become possible to approach all fiq-based rules functionally.

Functional approaches to fiq, as I established earlier, undermine the superior positions of entitled justice (idālati istihqāq $\vec{\imath}$ ) and proportional equality. Kadivar ([1382] 2004) appeals to 
the term qawām (supremacy) and indicates that in a number of verses, Allah speaks apparently of the supremacy of one gender, race, or group of people over another. In verse 34, sura an-Nisa, he points to the exaltation of the man over the woman. In verse 16, sura alJāsiya, and verse 140, sura al-A 'râff, the same relation between Jewish people on one hand and the people of Muhammad and Jesus on the other was implied. Through other verses (such as verse 42, sura äli Imrān), Allah chose Mary above all the women of the world. Nevertheless, in all of these verses, Allah mentions a conditioned exaltation which cannot be generalized to all times and all situations. In other words, he reminds us that time-specific virtues are not inherent supremacies. As far as the relationship between men and women in sura an-Nis $\bar{a}$ is concerned, the exaltation relates to the situations in which the superior physical strength of men was a central component of social life. Today, however, a great number of alternatives undermine this centrality. ${ }^{11}$

In sum, traditional $f i q$ and conservative ijtīha $d$ is unable to step beyond the limits of shari a to solve critical issues in the Muslim world. In other words, its essential character confines it to the boundaries of shari a and restricts it to go through the more radical ijtīha in $\bar{u} s \bar{u} l$ (principles). Nevertheless, reformist Islam is involved in the problem of criterion, in the sense that preserving the religious character of new interpretations requires different approaches to the classical Islamic sources of knowledge, including kitāb, Sunna, aql, and ijmā. In order to find a way out of this abyss, Kadivar ([1382] 2004) highlights three criteria that, in his opinion, were also in effect at the time of the revelation. The first concerns the rationality of the religious order during that time. Distinguishing between rational and irrational rules is related to the overall rationality of the time; common sense thus plays a critical role here. In addition, being rational is determined through the reference to not only the Sunna (the Qur'anic verses), but also to axioms such as the freedom of speech. Hence, the elements of new interpretations are not rational simply because of their conformity to the traditional sources of Islamic knowledge; rather, every new statement needs to satisfy the requirements of a more extended concept of the rational. Second, a comparison to the rules of other religions provides another basis for judging the rules of Islam. In the shadow of this criterion, the first Muslims found Islam more progressive and thus accepted the invitation. Here, the relative superiority to the existing traditions and norms is vital. Finally, every new interpretation needs to satisfy the basic conditions of equity and justice. As the first criterion, this is highly dependent on the overall sense of justice. The problem, as Kadivar says, is that over time, under the pressure of traditionalism, the aforementioned criteria have been largely overlooked. He instead believes that many so-called insolvable problems in shari a, especially in the context of women, children, human rights, and the like, can be reformulated in the light of a new methodological perspective.

\section{It could have been otherwise: a conclusion}

In their reformulation, the religious intellectuals in question proposed two distinct methodic strategies to return to the Qur'an itself: (a) archeological and (b) genealogical methods. Based on the archeological perspective, the holy text is a repository of answers to all sorts of questions. The only requisite is a methodic refinement that catalyzes the process of discovery. Rahman's historical hermeneutic method, for example, represents this perspective, where returning to the past means returning to the origin. Thus, as it becomes clearer, this view looks toward the history of Islam pathologically and suggests the kinds of solutions that get rid of purported distortions in the process of interpreting the Qur'an. 
The genealogical view of the return puts aside the pathology of the history of Islam and instead insists on the contingency of interpretations, or the idea that the act of interpretation is always contextual and temporal. Regardless of the accuracy and validity of historical interpretations, all have addressed temporal and contextual questions. What is important in this perspective is not returning to an original source to find the exact massage of Allah, but cultivating a recurring reference to an open-ended text in order to find new answers to new concrete issues.

Genealogy, or the idea of contingent interpretations, renders different advantages to the idea of return. First, it opens the door for divergent interpretations that struggle for supremacy. When some ideas find themselves in a dominant position, others are pushed to the margins, which allows them a later chance to come to the stage again. This method reinforces the internal approach to religious reform and opens doors to new subjective positions. The issue of the right to divorce, for example, is one of the most controversial cases for women's rights activists in Iran. Historically, three classes of separation can be identified: (a) $\operatorname{tal} \bar{a} q$ (in its literal meaning), where a husband is the plaintiff and applies for a separation while the wife wishes to remain married; (b) khul', where a wife wants to divorce but the husband does not; and (c) mubāra, which indicates that both husband and wife apply for separation. Notwithstanding these three types of separation in Islam, the first type has become dominant among Muslim societies today, as though Islam completely overlooked a woman's right to divorce. A genealogical historical analysis can provide Muslims with different historical evidence that it could have been otherwise.

A genealogical interpretation also affords religious intellectuals, drawing on the theory/ method of $i j m \bar{a}^{c}$, the opportunities to throw into doubt some existing religious rules and norms, particularly those that are controversial. Inasmuch as $i j m \bar{a}^{c}$ is a main methodic tool of accepting a new Islamic rule (hukm), its absence in the cases of current controversial phenomena (such as the presence of women in public places) provokes Muslim thinkers to elucidate alternative social conducts and argue in support of human wisdom. Since most of the Iranian intellectuals have tried to de-centralize the formal and state-led religious narratives, this strategy has become popular among them. Ghabel ([1392] 2014), for instance, attempted to find a new narrative on the hijāb. As he contends, notwithstanding the lack of plausible consensus, the head and neck cover has become the "red line" and the so-called "flag of Islam" (78).

As an outcome of Muslim intellectualism, a functional approach in tandem with a moralistic view to dislocating the dominant orthodoxy is able to fuel new practical tactics. In the absence of acceptable ijma $\bar{a}^{c}$, for instance, a functional approach to ahkām (Islamic rulings, including obligatory, strongly recommended, plausible, not recommended, and forbidden) replaces blind legalism with a more reflexive and contextual strategy. Based on this point of view, Ghabel ([1392] 2014) tries to demonstrate that, in the early years of Islamic society and due to some particular concrete requirements, the Qur'an, in verses 31 sura an-Nür, 53, and 59 sura al-Ahzāb, recommends that only free Muslim women veil their heads to distinguish themselves from women who are not free, such as slaves. His well-documented argument indicates that the rule of hijāb had nothing to do with sexual desire, protecting the boundary of family, and so on.

Although historically functional approaches are able to put forth some solutions, they are limited to concrete rituals or daily religious conducts (manāsik). Islamic reformism, however, requires more epistemological attempts that concern the substances of Islamic values and deal with the evolution of religious knowledge as well. The first task controls the 
instrumentalist desire in functionalism, which is concerned with the historical pertinence of norms and rituals. Nevertheless, religious conducts are usually multi-dimensional, and thus assessing the historical fitness of these values and norms neither can nor should be reduced to an instrumentally functional assessment. As stated earlier, religious intellectuals believe in a final origin as a milestone of reformism. A productive dialogue between past and present requires intellectuals not to devote all of their attention to the simple refinement of tradition, namely the elimination of the dysfunctional and so-called outdated ahkām. Accordingly, intellectuals contend that the first mission of religious reformism is to paint a moralistic picture of the spirit of Islam that provides Muslims with temporal and more comprehensive narratives. Moreover, their attempts, which recall Aufhebung (sublation) ${ }^{12}$ in the Hegelian sense (2018), take them beyond the simple reconciliation of Islam with Western modernity. As Rahman (1984: 134) states, the modernization of Islam and Islamicizing of the modern cannot be the final solution in Muslim societies. Today's Islamic societies need more dramatic changes than ad hoc adaptations to new requirements. Otherwise, there will be many challenges that call into question the originality of religious intellectualism.

\section{Acknowledgements}

The author wishes to thank Susanne Schröter for her warm support, Mehdi Semati, Ali Sabbaghi, and the anonymous reviewers for their comments on an earlier draft.

\section{Funding}

This article is part of a research project that has been done within the framework of the Hessian Ministry for Science and Art funded LOEWE research hub "Religious Positioning: Modalities and Constellations in Jewish, Christian and Muslim Contexts" at the Goethe University Frankfurt/JustusLiebig-Universität Gießen, and in cooperation with the Reimers Stiftung and the Forschungskolleg Humanwissenschaften Bad Homburg.

\section{ORCID iD}

Mohammad Rezaei (D) https://orcid.org/0000-0002-8926-0233

\section{Notes}

1. Abdolkarim Soroush (1945-) is one of the Iranian religious revisionists who was forced into exile.

2. Some examples, which were foregrounded by some Iranian religious intellectuals, are as follows: the infallibility of The Twelve (Shia Imams) (Soroush 2005), Islamic theology (Soroush [1372] 1994, [1376] 1998a), the negation of the holiness of the Qur'an (Mojtahed Shabestari [1395] 2017), casting intellectual and political doubt on Islamic philosophy (Dustdar [1382] 2004), criticizing the political histories of Muslim nations (Aghajari [1381] 2003), and finally, casting doubt on the moral efficacy of religion for modern life (Malekian [1396] 2017).

3. Soroush follows up this type of interpretation in his debate on the prophetic experience, the forms of the revelation, and the pluralistic sources for religious knowledge. See for example: Soroush [1372] 1994 and [1388] 2009.

4. Nevertheless, Soroush's theory is not clear about the quality of the aforementioned dialogical relationships between different types of knowledge. The problem is that he says nothing about how religious knowledge could affect physics, cosmology, biology, and other sciences in the modern age. Most of the examples he presents in his work concern the developments in the sciences and their impacts on religious knowledge. 
5. This is one of the most important criteria in Islamic jurisprudence, which allows the jurists to identify the priority of Islamic ordinances. Based on this principle, more important instances exclude the important ones (Muntaziri [1378] 2000, 15).

6. The idea of $i j t \bar{t} h \bar{a} d$ in $\bar{u} s \bar{u} l$ echoes across Mojtahid Shabestari's works as well, where he argues that wholesale concepts and our perceptions about Allah, the revelation, the Prophet life, Islamic law, fiq, and so on, need to be subjected to trenchant criticism. He contends that Muslims can become inured to the current, modern life if they look for a new understanding of the Prophet's message (see [1377] 1999 and 1395] 2017).

7. For a detailed criticism see Naraghi, [1372] 1994.

8. This term, generally speaking, in shi a fiq, refers to a leadership position in society, but here it is applied to Imam jamā'at (the turbaned leader of any of the five daily prayers said by worshippers at a mosque or elsewhere), and Imam Jum' $a$ (the leader of mid-day congregational Friday prayers).

9. For a further description, refer to the rule of identification of religion and reason (mulazzima aql va $\left.d_{i n}\right)$ : "Whatever which is determined by religion, is also determined by reason and vice versa." It is noteworthy that, the second part of the axiom, that is, "whatever which is determined by reason, is also determined by religion" shows a real controversy among the Islamic jurists. In fact, the limits of aql capacities here are at stake. Jurists believe that every religious statement is rational (the principal or the essential identification of religion and reason). The second part of the aforementioned rule, however, provokes controversy in the sense that not every rational statement is necessarily religious (adjunct identification of religion and reason). The significance of this rule leads Islamic jurists to the defect of reason as a very characteristic of human reason.

10. Salaf means:

... the virtuous forefathers, and a person who draws on the Qur'an and the Sunnah as the only valid sources of Islam. The Salaf included the Prophet's companions and the early generations of Islam, ending with Ahmad Ibn Hanbal in the ninth century, although a number of later Islamic scholars are included. (Adamec 2009, 274)

11. Needless to say, my argument on the functionalist approach is based on the few number of shi $i$ intellectuals. Scholars with different backgrounds from other Islamic denominations would have their own various interpretations of disputed verses and concepts such as qawäm, imāmat, and so on.

12. This word means negation, preserving, and to transcend.

\section{References}

Adamec Ludwig, W. 2009. Historical Dictionary of Islam. Maryland: The Scarecrow Press.

Adib-Moghaddam, Arshin. 2015. "Islamic Secularism and the Question of Freedom in Iran." Middle East Critique 25, no. 1: 71-82.

Aghajari, Hashem. (1381) 2003. Lecture in Hamadan, Statement of Defence, Indictment [Sukhanrān̄̄ Hamadan, Lāyiha Difäiya, kiyfarkhāst]. Tehran: Jamedaran Publications.

Alavitabar, Alireza. (1380) 2002. "Religious Intellectualism: A Progressive Agenda" [Rushanfikrī Dīn̄̄: Yik Barnāma Pishru]. Baztabi Andisha 22: 20-27.

Arkoun, Mohammad. (1374) 1996. "What Does Toleration Mean in Islamic Society?" [Bi Chi Ma 'nā Mìtavān az Tasāmuh dar Jami 'a Islāmī Sukhan Guft]. Translated by M.M. Khalaji. Kiyan 27: $18-21$.

Arkoun, Mohammad. (1378) 2000. "The Criticism of the Islamic Reason and the Concept of Allah" [Naqdi Aqli Islāmī and Mafhūmi Khudā]. Kiyan 47: 17-27.

Boroujerdi, Mehrzad. 1996. Iranian Intellectuals and the West: The Tormented Triumph of Nativism. Syracuse: Syracuse University Press.

Dustdar, Aramesh. (1382) 2004. The Impossibility of Religious Thought [Imtinā'i Tafakkuri Dīn̄̄]. Paris: Khavaran. 
Foucault, Michael. 1977. "The Confession of the Flesh." In Power/Knowledge Selected Interviews and Other Writings, edited by Colin Gordon, 194-228. New York: Pantheon Books.

Ghabel, Ahmad. (1392) 2014. Women Sensitive Rulings in Islamic Shari a [Ahkāmi Bānuvān dar Shar̄̄'ati Muhammadi]. Tehran: Shari'ati Aqlani.

Ghobadzadeh, Naser and Lily Zubaideh Rahim. 2012. "Islamic Reformation Discourses: Popular Sovereignty and Religious Secularisation in Iran." Democratization 19, no. 2: 334-351.

Golkar, Said. 2012. "Cultural Engineering under Authoritarian Regimes: Islamization of Universities in Post-Revolutionary Iran." Digest of Middle East Studies 21, no. 1: 1-23.

Gramsci, Antonio. 1971. Selections from Prison Notebooks of Antonio Gramsci. Translated by Quentin Hoare and Geoffrey Nowell Smith. London: Elecbook.

Hegel, Georg Wilhelm Friedrich. 2018. The Phenomenology of Spirit. Translated by Terry Pinkard. Cambridge: Cambridge University Press.

Jahanbakhsh, Forough. 2003. "Religious and Political Discourse in Iran: Moving Toward PostFundamentalism." The Brown Journal of World Affairs 9, no. 2: 243-254.

Jahanbakhsh, Forough. 2004. "The Emergence and Development of Religious Intellectualism in Iran." Historical Reflections/Réflexions Historiques 30, no. 3: 469-489.

Kadivar, Mohsen. (1380) 2002. "From Historical to Spiritual Islam" [Az Islāmi Tārìkh̄̄ tā Islāmi Ma 'navi]. Accessed October 28, 2018. https://kadivar.com/?p=1078

Kadivar, Mohsen. (1382) 2004. "Human Rights and Religious Intellectuals" [Huqūqi Bashar va Rushanfikrī Dīnī]. Accessed October 29, 2018. https://kadivar.com/?p=1069

Kadivar, Mohsen. (1390) 2012. “An Overview in Women's Rights in Islam: Entitled Justice Instead of Equity-Based Justice" [Bazkhān̄̄ Huqūqi Zanān dar Islām: Idālati Musāvātī bi Jāyi Idālati Istihqāqī]. Accessed October 28, 2018. https://kadivar.com/?p=8931

Kadivar, Mohsen. (1396) 2018. "Women's Rights and Religious Intellectuals" [Huqūqi Zanān va Rushanfikrī Dīnī]. Accessed October 24, 2018. https://kadivar.com/?p=16439

Malekian, Mostafa. (1396) 2017. "Unproved Presumption of Religious Foundation of Ethics" [Pishfarzhāyi Isbāt Nashuda Akhlāq]. Accessed June 20, 2018. https://3danet.ir/

Mirsepassi, Ali. (1380) 2001. Iranian Intellectuals and Modernity [Rushanfikrāni Irān̄̄ va Mudirnīta]. Tehran: Baz Publication.

Mirsepassi, Ali. (1381) 2002. Democracy or Truth: A Sociological Thesis on Iranian Intellectuals [Dimukrās̄̄ yā Haqūqat: Risāla Jami shinākht̄̄ Darbāra Rushanfikrāni Irān̄̄]. Tehran: Tarhi No.

Mirsepassi, Ali. 2000. Intellectual Discourse and the Politics of Modernization: Negotiating Modernity in Iran. Cambridge: Cambridge University Press.

Mojtahed Shabestari, Mohammd. (1377) 1999. "Religion, Toleration, and Violence" [D̄̄n, Mudārā, va Khushūnat]. Kiyan 45:6-19.

Mojtahed Shabestari, Mohammad. (1395) 2017. "A Critique of the Foundations of Fiq and Kalam" [Naqdi Bunyādhāyi Feq hu Kalām]. Accessed October 24, 2018. http://mohammadmojtahedsh abestari.com/1282-2/

Muntaziri, Hossein Ali. (1378) 2000. "On Conflict" [Darbāra Tazāhum]. Keyan 45:1-10.

Naraghi, Ahmad. (1372) 1994. "A More Profound Understanding? Questioning Theory of Constriction and Expansion of Shari 'a" [Fahmi Amiqtar? Pursish az Nazarìya Qabz va Bast]. Kiyan 3, no.11: 16-20.

Nasr, Seyyd Hossein, Caner K. Dagli, Maria Massi Dakake, Joseph E.B. Lumbard, Mohammed Rustom. 2015. The study Qur'an: A new translation and commentary. California: Harper One.

Rahman, Fazlur. 1965. Islamic Methodology in History. Islamabad: Islamic Research Institute.

Rahman, Fazlur. 1984. Islam and Modernity: Transformation of an Intellectual Tradition. Chicago: The University of Chicago Press.

Saffari, Siavash. 2015. "Rethinking the Islam/Modernity Binary: Ali Shariati and Religiously Mediated Discourse of Socio-political Development." Middle East Critique 24, no.3: 231-250.

Soroush, Abolkarim. (1372) 1994. Theoretical Constriction and Expansion of Shari'a: The Theory of Evolution of Religious Knowledge [Qabz va Basti Tiurīki Sharīáat: Nazarīya Takāmul̄ Ma'rifati Dīnì]. Tehran: Serat. 
Soroush, Abdolkarim. (1370) 1992. "Constriction and Expansion under Scrutiny" [Qabz va Bast dar Mīzāni Naqd va Bahs]. Kiyan 42: 5-13.

Soroush, Abdolkarim. (1376) 1998a. "Substantial and Accidental in Religion" [Zātī va Arazī dar Dīn]. Kiyan 8, no. 42: 4-19.

Soroush, Abdolkarim. (1376) 1998b. "Weighing Fiq: Asking Some Question of Ayatullāh Muntaziri” [Fiq dar Tarāzū: Chand Pursish az Ayatullāh Muntaziri]. Kiyan 46: 14-21.

Soroush, Abdolkarim. (1388) 2009. Straight Paths: On Religious Pluralism [Sirāthāyi Mustaqūm: Sukhān̄ dar Plūratı̀smi Dīn̄̄]. Tehran: Serat.

Soroush, Abdolkarim. 1996. "A Conversation with Abdolkarim Sorush." Q-News International (British Muslim Weekly). no. 220-21 (June) Accessed December 12, 2018. http://www.drsoroush. com/English/Interviews/E-INT-19960614-A_conv

Soroush, Abdolkarim. 2005. "Shiism and the Challenge of Democracy: A Lecture among the Iranian College Students in Paris." Accessed June 24, 2018. www.drsoroush.com

Tajmazinani, Ali Akbar. 2017. "From Cultural Revolution to Cultural Engineering: Cultural Policy in Post-Revolutionary Iran." In The Routledge Handbook of Global Cultural Policy, edited by Victoria Durrer, Toby Miller and Dave O'Brien, 503-519. London and New York: Routledge.

The Qur'an. 1997. Translated by Taqi-ud-Din Al-Hilali and Muhammad Mohsin Khan. K.S.A., Madinah: King Fahad Complex for the Printing of the Holy Qur'an.

\section{Author biography}

Mohammad Rezaei is a researcher at Frankfurter Forschungszentrum Globaler Islam (FFGI), Goethe University Frankfurt. His books are Contradictions of Schooling in Iran: An Analysis of Students' Everyday life (Society and Culture Pub., 2007), Fractures in Iranian Society (Agah Pub. 2016), The Emancipatory Cultural Studies (forthcoming), and The Article 24: A Genealogy of Book Censorship in Iran (forthcoming). He is on the editorial boards the Journal of Iranian Cultural Research and the Journal of Cultural Studies and Communication. 